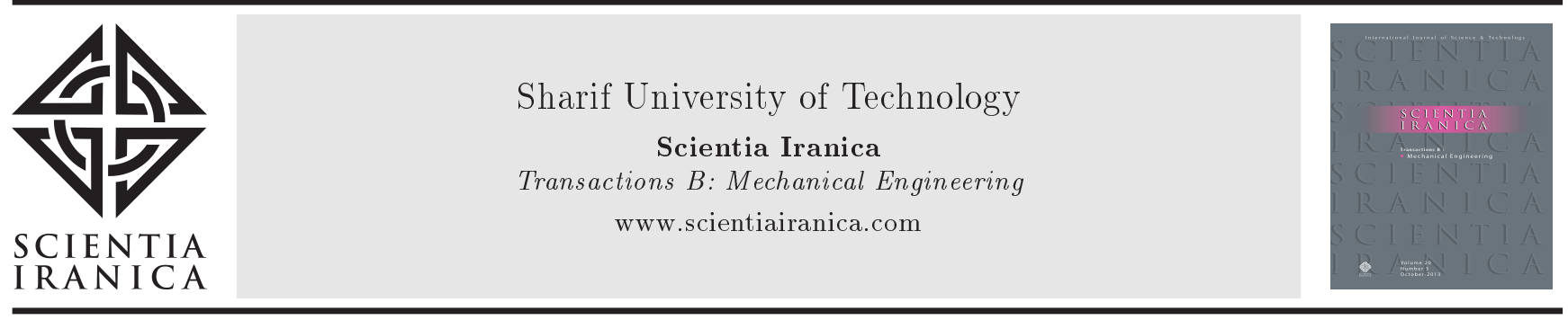

\title{
Various types of ceramics used in radome: A review
}

\author{
M. Saeedi Heydari ${ }^{a, *}$, J. Ghezavati ${ }^{\mathrm{b}}$, M. Abbasgholipour ${ }^{\mathrm{c}}$ and \\ B. Mohammadi Alastic \\ a. Young Researchers and Elite Club, South Tehran Branch, Islamic Azad University, Tehran, P.O. Box: 4435/11365, Iran. \\ b. Young Researchers and Elite Club, Bonab Branch, Islamic Azad University, Bonab, Iran. \\ c. Department of Mechanical Engineering, Bonab Branch, Islamic Azad University, Bonab, P.O. Box: 55518/134, Iran.
}

Received 3 November 2015; received in revised form 2 May 2016; accepted 2 July 2016

\section{KEYWORDS}

Radome;

Silicon nitride;

Dielectric constant;

Strength.

\begin{abstract}
Advanced tactical missiles need radomes of higher strength capable of withstanding higher velocities and temperatures and longer flight durations. Radomes must be stable at temperature above $1400^{\circ} \mathrm{C}$ and must have a low and steady thermal dielectric constant, low thermal expansion coefficient, high resistance to thermal shock, high stiffness and strength, high chemical stability, and high resistance against moisture. Silicon nitride, in comparison with other materials used in the fabrication of radomes (e.g., fused Silica, pyroceramics, etc.), enjoys superior properties, and it can also be used at flight speeds higher than Mach 7. In this paper, various types of raw materials used in the fabrication of radomes have been investigated.
\end{abstract}

(C) 2017 Sharif University of Technology. All rights reserved.

\section{Introduction}

Radomes are considered as one of the main components of modern radar-controlled missiles. Radar units are often used in environments that expose them to physical damage. In these situations, radomes are employed to protect the radar units. A radome head not only protects the antenna section from the air flow and aerodynamic disturbances, but also determines the properties of a missile and its homing accuracy and receives the major forces and thermal loads during a maneuver. In addition, a radome allows the electromagnetic waves to pass through $[1,2]$. Radomes must be able to resist any real reaction that may emerge during an operation and must keep their strength and engineering properties intact [2]. Therefore, a radome is used as a structural part to protect a radar unit

*. Corresponding author. Tel.: +982122464821 E-mail addresses: minasaeedi85@gmail.com (M. Saeedi Heydari); ghezavati905@gmail.com (J. Ghezavati); M.A_POUR@yahoo.com (M. Abbasgholipour); behzad.alasti@gmail.com (B. Mohammadi Alasti) while having the least interference in its electrical performance [3].

There are various types of radomes, depending on the conditions in which they are used. Inorganic wall materials come into their own, particularly when organic materials fail due to the loss of strength at higher temperatures. Most organic materials are not suitable at $250^{\circ} \mathrm{C}$ and even the best can only survive a short term at $500^{\circ} \mathrm{C}$. In general, density, dielectric, mechanical, thermal, and environmental properties are those of interest. Based on the type of raw material used in radome fabrication, a brief review of the comparison of some of the most common candidate materials (alumina, pyroceramic, silica, cordierite, and silicon nitride) is given in Table 1 [4].

In terms of shape, radomes are classified as conical-spherical, ogival, or flat radomes [2]. The most common nose shapes are conical, tangent or secant ogive, elliptical or hemispherical, power series, parabolic series, Haack series, or Von Karman. Some of the nose cone shapes are shown in Figure 1 [5]. Below Mach 0.8 , the nose pressure drag is essentially zero for all shapes and the pressure drag increases dramatically 
Table 1. Comparing the properties of the most common candidate radome materials [4].

\begin{tabular}{|c|c|c|c|c|c|c|c|}
\hline \multirow[b]{2}{*}{ Property } & \multirow[b]{2}{*}{$\begin{array}{c}\text { Alumina } \\
99 \%\end{array}$} & \multirow[b]{2}{*}{ Pyroceram } & \multicolumn{2}{|c|}{ Silica } & \multirow[b]{2}{*}{$\begin{array}{l}\text { Cordierite } \\
\text { Rayceram }\end{array}$} & \multicolumn{2}{|c|}{ Silicon nitride } \\
\hline & & & $\begin{array}{c}\text { Slip } \\
\text { cast } \\
\text { fused }\end{array}$ & $\begin{array}{c}\text { With } \\
\text { woven } \\
\text { quartz }\end{array}$ & & Dense & $\begin{array}{c}\text { Reaction } \\
\text { bonded }\end{array}$ \\
\hline Density gr. c.c. & 3.9 & 2.6 & 2.2 & 1.8 & 2.45 & 3.2 & 2.4 \\
\hline \multicolumn{8}{|l|}{ Dielectric constant } \\
\hline $10 \mathrm{GHz} 25^{\circ} \mathrm{C}$ & 9.6 & 5.65 & 3.42 & 3.05 & 4.85 & 7.9 & 5.6 \\
\hline $500^{\circ} \mathrm{C}$ & 10.3 & 5.8 & 5.8 & 3.04 & 5.05 & 8.2 & 5.7 \\
\hline $1000^{\circ} \mathrm{C}$ & 11.4 & 6.1 & 3.8 & 3.02 & - & - & 5.8 \\
\hline \multicolumn{8}{|l|}{ Loss tangent } \\
\hline $10 \mathrm{GHz} 25^{\circ} \mathrm{C}$ & 0.0001 & 0.0002 & 0.0004 & 0.0009 & 0.002 & 0.004 & 0.001 \\
\hline $500^{\circ} \mathrm{C}$ & 0.0005 & 0.001 & 0.001 & 0.001 & 0.008 & 0.0045 & 0.0025 \\
\hline $1000^{\circ} \mathrm{C}$ & 0.0014 & - & - & - & - & - & - \\
\hline \multicolumn{8}{|l|}{ Flexural strength } \\
\hline \multicolumn{8}{|l|}{$\mathrm{N} / \mathrm{m}^{2} * 10^{6}$} \\
\hline $25^{\circ} \mathrm{C}$ & 270 & 235 & 44 & - & 125 & 400 & - \\
\hline $500^{\circ} \mathrm{C}$ & 250 & 200 & 54 & - & 120 & 400 & - \\
\hline $1000^{\circ} \mathrm{C}$ & 220 & 75 & 66 & - & - & - & - \\
\hline \multicolumn{8}{|l|}{ Young modulus } \\
\hline \multicolumn{8}{|l|}{$\mathrm{N} / \mathrm{m}^{2} * 10^{9}$} \\
\hline $25^{\circ} \mathrm{C}$ & 380 & 120 & 48 & 18 & 128 & 300 & - \\
\hline $500^{\circ} \mathrm{C}$ & 250 & 120 & 48 & - & 125 & 300 & - \\
\hline $1000^{\circ} \mathrm{C}$ & 285 & 100 & - & - & 120 & - & - \\
\hline Thermal shock & Fair & Good & Very good & Very good & Good & Very good & Very good \\
\hline Water absorption & $0 \%$ & $0 \%$ & $5 \%$ & $20 \%$ & $0 \%$ & - & $20 \%$ \\
\hline Rain erosion & Excellent & Very good & Poor & Poor to fair & Very good & Very good & Good \\
\hline
\end{tabular}

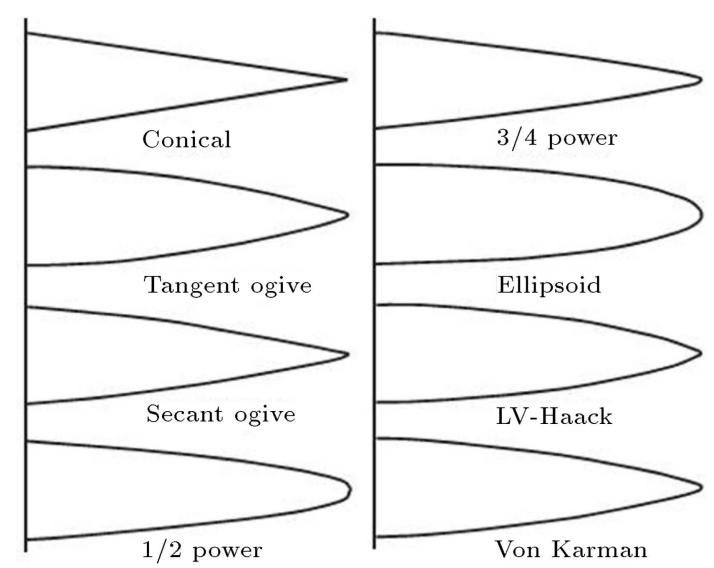

Figure 1. Different types of radome nose shapes [9].

in the transonic region and beyond, where the effect of nose shape on drag becomes highly significant. The factors influencing the pressure drag are the general shape of the nose cone, its fineness ratio, and its bluffness ratio. The ratio of the length of a nose cone compared with its base diameter is known as the fineness ratio. At supersonic speeds, the fineness ratio has very significant effect on nose cone wave drag. Fineness ratio of 5 is critical as the fineness ratio increases, and the wetted area and the skin friction components of drag increase [6]. Most commercially made tangent ogive nose cones are blunt for a bluffness ratio of about 0.1 . Comparison of drag for different nose shapes of the radomes is shown in Figure 2 [7].

Based on the wall electrical thickness, radomes are divided into thin-walled or half-wave radomes, and single and multilayer (two-layer or three-layer) radomes [2]. Conventionally, the radome is designed to be a single wall structure in which wall thickness is equivalent to an electron thickness of $1 / 2$ wavelength. However, this structure has a very narrow bandwidth and lacks adequate strength when the wavelength is $<2 \mathrm{~cm}$. Multilayer broadband designs, known as A-, B-, and C-sandwich structures, have been proposed to solve this problem [8]. As shown in Figure 3, the radome wall structure greatly determines the use of the defined frequencies or broadband (1-18 GHz) wave transmission, and half-wave wall structure is 


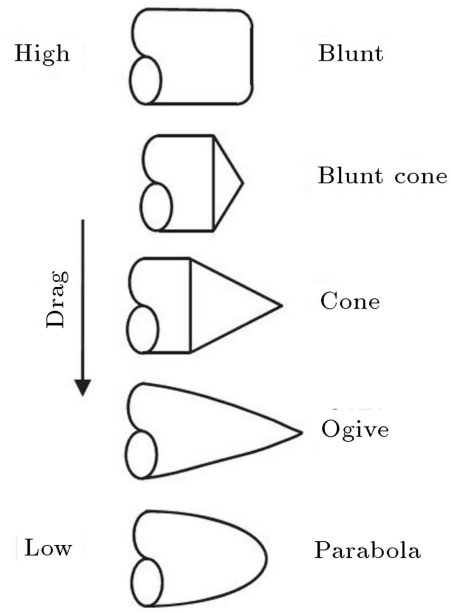

Figure 2. Performance of drag on various nose shapes [57].

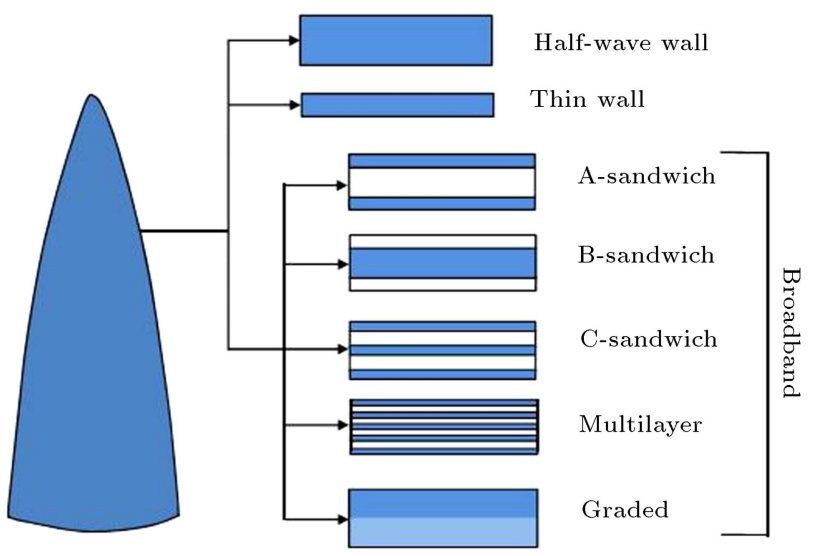

Figure 3. Schematic diagram of radome wall structure [9].

used for the defined frequency application [9]. The most commonly used and reported broadband radome wall structure consists of A-sandwich, C-sandwich, and multilayer. However, these structures are not suitable for high-temperature environment due to the big mismatch of the thermal properties of each layer, which may restrain their application in the high-speed missile radome [5]. The structure is designed to be composed of an odd multiple layers with no central matching layers at the design frequency. Investigations show that the multilayer structures exhibit multiband transmission property [10]. To relieve the thermal stresses between the layers, functionally-graded material has been developed and is used for ultrahigh temperature application [11]. The necessary properties of materials utilized in the fabrication of radomes are listed in Table $2[1,2]$.

With the increase in the speed of modern aircrafts, more superior properties are required. When radomes are used at high speeds (Mach 3 to Mach 5), their physical and mechanical properties must be con-
Table 2. Necessary properties of materials used in radomes $[1,2]$.

\begin{tabular}{lc}
\hline \multicolumn{1}{c}{ Properties } & Required \\
\hline Service temperature & Up to $1400^{\circ} \mathrm{C}$ \\
Dielectric constant & $<9.0(5.0$ preferred $)$ \\
Temperature variation of & $<7.0 \%$ \\
dielectric constant to $1260^{\circ} \mathrm{C}$ & $<0.1$ \\
Loss tangent to $1260^{\circ} \mathrm{C}$ & $>35 \mathrm{MPa}(5 \mathrm{KSi})$ \\
Bending strength $(4$ point $)$ & \\
\hline
\end{tabular}

sidered for a temperature range of $500-800^{\circ} \mathrm{C}$ and for tougher environmental conditions [3]. For the first time, in 1956, the application of ceramic materials for radomes, as well as for missile guidance, was proposed in the Rutgers University by considering the use of glass-reinforced plastic; however, this material could not be used at high temperatures and was only suitable for speeds close to Mach 3 [2]. For higher speeds, ceramic materials would be required, which normally include $\mathrm{Al}_{2} \mathrm{O}_{3}$, slip-cast fused $\mathrm{SiO}_{2}$, and cordierite, with each one having its own limitations. $\mathrm{Al}_{2} \mathrm{O}_{3}$ has low resistance to thermal shock and a high dielectric constant. Cordierite properties are between those of $\mathrm{Al}_{2} \mathrm{O}_{3}$ and $\mathrm{SiO}_{2}$; however, when used at temperatures above $600^{\circ} \mathrm{C}$, it has relatively high dielectric loss [3].

Table 3 gives the dielectric constant and loss tangent for slip cast silica, alumina, and Pyroceram 9606. It is generally agreed that a radome material can undergo maximum change in dielectric constant of approximately 10 per cent and still be effective. Based on this value, alumina and Pyroceram 9606 can be used up to approximately $2000 \mathrm{~F}$ and fused silica to $2500 \mathrm{~F}$. Note that for the slip-cast fused silica, there is essentially no change in dielectric constant up to $1500 \mathrm{~F}$, and that the change is only 7.9 per cent at $2500 \mathrm{~F}$. The loss tangent, which is a measure of the energy lost passing through a material, can be seen to be extremely low for all of the materials. Thus, silica is the most likely choice of materials in applications where stable electrical properties at elevated temperatures are of prime concern fused, but it has very low resistance to moisture and abrasion $[3,12]$.

The dielectric constant and the loss tangent are very important parameters for wave-transparent materials. In order to use them as radomes, these materials must have low dielectric constant and loss tangent values so that they can reduce the reflection and absorption of wave energy. Usually, at frequencies between 0.3 and $30 \mathrm{GHz}$, wave-transparent materials should have a dielectric constant between 1-4 and a loss tangent between $10^{-3}-10^{-1}$. The dielectric constant and the loss tangent that remain constant at the service temperature are also important factors, because the values of these parameters at the service temperature are the bases for optimizing the thickness of a radome wall, and a considerable variation in the 
Table 3. Elevated temperature electrical properties of radome materials [12].

\begin{tabular}{ccccc}
\hline Material & $\begin{array}{c}\text { Temperature } \\
(\mathbf{F})\end{array}$ & $\begin{array}{c}\text { Dielectric } \\
\text { constant at } \\
\mathbf{9 3 7 5} \mathbf{~ M c}\end{array}$ & $\begin{array}{c}\text { Per Cent } \\
\text { change }\end{array}$ & $\begin{array}{c}\text { Loss tangent } \\
\text { at 9375 Mc }\end{array}$ \\
\hline \multirow{2}{*}{ Alumina } & 75 & 9.3 & - & 0.0001 \\
& 500 & 9.5 & 2.6 & 0.0001 \\
& 1000 & 9.8 & 5.4 & 0.0002 \\
& 1500 & 10.1 & 8.6 & 0.0006 \\
Pyroceram & 2000 & 10.3 & 10.8 & 0.003 \\
\hline 9606 & 75 & 5.5 & - & 0.0003 \\
& 500 & 5.5 & - & 0.0005 \\
& 1000 & 5.55 & 0.9 & 0.0018 \\
& 1500 & 5.7 & 3.6 & 0.009 \\
Slip cast & 2000 & - & $>10$ & 0.009 \\
fused silica & 75 & 3.17 & - & 0.0002 \\
& 500 & 3.17 & - & 0.0003 \\
& 1000 & 3.17 & - & 0.0004 \\
& 2000 & 3.18 & 0.315 & 0.0006 \\
\hline & 2500 & 3.28 & 3.15 & 0.007 \\
& & 3.42 & 7.9 & 0.012 \\
\hline
\end{tabular}

high service temperature reduces the transparency of radomes against waves. The increase of the loss tangent with temperature can be due to polarization at elevated temperatures [13]. $\mathrm{Si}_{3} \mathrm{~N}_{4}$ has an acceptable dielectric constant and a low dielectric loss $(\tan \delta=0.002$ at temperatures above $800^{\circ} \mathrm{C}$, where $\delta$ is the angle of energy loss). Owing to properties such as high mechanical strength, good resistance to thermal shock, excellent resistance to wear and abrasion by water, sand, etc., this substance is a suitable candidate for high-temperature radomes [14,15].

Due to the importance of the properties of raw materials used in the fabrication of radomes, this paper has investigated various types of substances that are utilized for this purpose.

\section{Alumina}

From all the metal oxides available, the use of alumina $\left(\mathrm{Al}_{2} \mathrm{O}_{3}\right)$ in radomes has been extensively researched, and various forms of radomes made of this substance have been used in the present-day missiles for speeds above Mach 2 [16]. Based on the findings of the Materials Research Center in the U.S., radomes made of $\mathrm{Al}_{2} \mathrm{O}_{3}$ with a purity higher than $97 \%$ can operate at temperatures above $1760^{\circ} \mathrm{C}$. Lucalox, which is $99.9 \%$ pure, is considered as one of the best substances based on the aluminum oxide. By adding a little magnesium oxide to Lucalox, the growth of grains in this substance is delayed and a high density material is achieved [17]. $\mathrm{Al}_{2} \mathrm{O}_{3}$-based ceramics are waterproof and ex- tremely resistant to different chemicals. The dielectric constant of pure aluminum oxide at room temperature and frequency range of $0.8 \times 10^{10}-2.5 \times 10^{10} \mathrm{~Hz}$ is 9.6 , which drops considerably by raising the temperature to $800^{\circ} \mathrm{C}$. The loss tangent of this material is between $5 \times 10^{-4}-10 \times 10^{-4}$. However, $\mathrm{Al}_{2} \mathrm{O}_{3}$-based materials undergo substantial contraction which depends on the amounts of adhesive and applied pressure in the casting phase; therefore, some mechanisms should be implemented for the prevention of deformation during the sintering process.

The high sintering temperatures, significant contraction of the preform during sintering, warping and deformation, high strength and stiffness, machining difficulty, low resistance to thermal shock, and a high dielectric constant are the drawbacks that have limited the use of this material in radomes exposed to high speeds. The properties of some $\mathrm{Al}_{2} \mathrm{O}_{3}$-based materials are listed in Table 4 [2].

\section{Pyroceramics}

In 1957, a glass manufacturing company introduced a new material called "pyroceramic", which is a type of microcrystalline glass. Pyroceramic is a nonporous crystalline glass material with density of 2.4$2.62 \mathrm{gr} / \mathrm{cm}^{3}$. The mechanical strength and the dielectric constant of pyroceramic do not change almost up to $700^{\circ} \mathrm{C}$, and its loss tangent at temperatures above $750^{\circ} \mathrm{C}$ is 0.02 . In comparison to $\mathrm{Al}_{2} \mathrm{O}_{3}$-based ceramics, pyroceramics are more stable against tem- 
Table 4. High-alumina ceramic properties [2].

\begin{tabular}{lccc}
\hline \multirow{2}{*}{ Properties } & \multicolumn{3}{c}{ Material grade } \\
\cline { 2 - 4 } & AL-300 & TSM-300 & TSM-303 \\
\hline Apparent density, g/cm ${ }^{3}$ & $3.80-3.96$ & $3.98-4.00$ & $3.68-3.82$ \\
Ultimate strength in bending, MPa & $300-400$ & $240-265$ & 300 \\
Thermal conductivity, W/(m.K) & $20-80$ & - & - \\
LTEC, $10^{-7} \mathrm{~K}^{-1}$ & $85-110$ & $58.7-75.1$ & $68-87$ \\
$\varepsilon$ with frequency $f=10^{10} \mathrm{~Hz}$ & $8.2-9.6$ & $9.87-10$ & $9.0-9.5$ \\
$\operatorname{tg} \delta$ with frequency $f=10^{10} \mathrm{~Hz}$ & $\leq 0.001$ & $>5 \times 10^{-4}$ & $>5 \times 10^{-4}$ \\
Poisson's ratio & - & 2.2 & - \\
\hline
\end{tabular}

Table 5. Properties of several grades of pyroceramic [2].

\begin{tabular}{lccccccc}
\hline \multicolumn{1}{c}{ Properties } & \multicolumn{7}{c}{ Pyroceramic grade } \\
\cline { 2 - 6 } & $\mathbf{8 6 0 5}$ & $\mathbf{8 6 0 6}$ & $\mathbf{9 6 0 6}$ & $\mathbf{9 6 0 8}$ & $\mathbf{9 6 0 5}$ & AS-370 & AS-418 \\
\hline Elasticity modulus, $10^{4} \mathrm{MPa}$ & 14.0 & 12.0 & 12.1 & 8.8 & 13.0 & 13.2 & 9.0 \\
Ultimate strength in bending, $\mathrm{MPa}$ & 260 & 225 & $120-260$ & $110-130$ & - & $170-210$ & $100-145$ \\
Softening temperature, ${ }^{\circ} \mathrm{C}$ & 1350 & 1250 & 1350 & 1250 & - & - & - \\
Water absorption, $\%$ & 0 & 0 & 0 & 0 & - & $\leq 0.02$ & $\leq 0.02$ \\
Apparent density, $\mathrm{g} / \mathrm{cm}^{3}$ & 2.62 & 2.60 & 2.61 & 2.50 & - & $2.6-2.7$ & $2.5-2.6$ \\
Specific heat capacity at $25-400^{\circ} \mathrm{C}, \mathrm{KJ} /(\mathrm{kg} . \mathrm{K})$ & 0.102 & 0.105 & $0.8-1.3$ & $1.2-1.75$ & - & $0.9-1.3$ & $0.5-1.1$ \\
Thermal conductivity, $\mathrm{W} /(\mathrm{m} . \mathrm{K})$ & 4.15 & 2.94 & $2.2-3.0$ & $1.8-2.0$ & - & $2.1-3.1$ & $1.8-2.0$ \\
Knoop hardness with load, $\mathrm{g}: 50$ & 1100 & 940 & - & - & - & - & - \\
Knoop hardness with load, $\mathrm{g}: 100$ & - & - & 698 & 820 & - & - & - \\
LTEC at 25-300 ${ }^{\circ} \mathrm{C}, 10^{-7 \circ} \mathrm{C}-1$ & 47 & - & 57 & $5-13$ & 21 & - & - \\
Poisson's ratio & - & - & 0.245 & 0.29 & 0.245 & - & - \\
$\varepsilon$ with frequency $f=10^{10} \mathrm{~Hz}$ and $20^{\circ} \mathrm{C}$ & - & - & 5.7 & 6.9 & - & 6.7 & 7.5 \\
tg $\delta$ with frequency $f=10^{10} \mathrm{~Hz}$ and $20^{\circ} \mathrm{C}$ & - & - & 0.0002 & - & - & 0.0012 & 0.015 \\
Thermal shock resistance $\Delta T,{ }^{\circ} \mathrm{C}$ & - & - & 350 & 550 & - & 400 & 600 \\
\hline
\end{tabular}

perature variations at higher temperatures and they better disperse the heat. During flights at an altitude of $30 \mathrm{~km}$ and speed of Mach 5, the surface of pyroceramic reaches $700^{\circ} \mathrm{C}$. Under similar conditions, $\mathrm{Al}_{2} \mathrm{O}_{3}$ heats up to $980^{\circ} \mathrm{C}$. The higher moisture resistance and the lower density of pyroceramics relative to $\mathrm{Al}_{2} \mathrm{O}_{3}$-based ceramics have led to their use as radomes [2].

The first material that was introduced as a pyroceramic was Pyroceram $9606\left(2 \mathrm{MgO} .2 \mathrm{Al}_{2} \mathrm{O}_{3} .5 \mathrm{SiO}_{2}\right.$, cordierite). This substance is a magnesium-aluminum silicate compound with high thermal shock resistance and resistance against corrosion and abrasion. This material is more resistant against corrosion than fused silica; however dielectrically, it is not stable against temperature variations and cannot be used at speeds higher than Mach 5. In trying to meet this requirement, two other compounds were examined; however, these two had different amounts of the secondary phase, such as crystobalite and magnesium tianate. Hallse et al. have shown that a material called Pyroceram 9603 enjoys a better thermal performance, but its loss tangent is greater. The main properties of several pyroceramics are presented in Table $5[2,16]$.

\section{Fused silica}

In the years of 1945-50, radome manufacturers widely used fused silica or quartz glass, which enjoys properties such as low thermal conductivity $(0.8 \mathrm{~W} / \mathrm{m} . \mathrm{K})$, low thermal expansion coefficient $\left(0.54-0.7^{*} 10^{-6} /{ }^{\circ} \mathrm{C}\right)$, low density, suitable mechanical strength, good resistance against thermal shock (no breakage after more than 20 thermal shock cycles between $25^{\circ} \mathrm{C}$ and $1000^{\circ} \mathrm{C}$ ), and high electrical resistance $[2,18,19]$. Furthermore, the fabrication of radomes using this material is done through slip casting, which is a simple process. The properties of some of the fused silica ceramics and composites that are reported by different researchers are given in Table 6 [18]. Figure 4 shows the flow diagram for the production of radomes made of quartz ceramics [20]. Compared to other materials, quartz ceramic is dielectrically more stable at higher tem- 
Table 6. Summary of the properties of various fused silica ceramics and composites [2].

\begin{tabular}{|c|c|c|c|c|c|}
\hline Composition & $\begin{array}{l}\text { Density } \\
\left(\mathrm{g} / \mathrm{cm}^{\mathbf{3}}\right)\end{array}$ & $\begin{array}{c}\text { Dielectric } \\
\text { permittivity }\end{array}$ & $\begin{array}{c}\text { Loss } \\
\text { tangent }\end{array}$ & $\begin{array}{l}\text { Strength } \\
(\mathrm{MPa})\end{array}$ & $\begin{array}{l}\text { Forming } \\
\text { methods }\end{array}$ \\
\hline - & 2 & 3.3 & 0.003 & 43 & - \\
\hline - & 2.2 & $3.42-3.8$ & $0.0004-0.001$ & $43-65$ & $25-1000^{\circ} \mathrm{C}$ at $10 \mathrm{GHz}$ \\
\hline - & - & $\begin{array}{c}3.06-3.16 \\
\left(25-1100^{\circ} \mathrm{C}\right)\end{array}$ & $\begin{array}{l}5.47 \times 10^{-4}- \\
3.61 \times 10^{-3}\end{array}$ & - & - \\
\hline$+3 \% \mathrm{BN}$ & 1.85 & - & - & 45 & Gelcasting \\
\hline \multirow[t]{2}{*}{+1 wt $\%$ nano $\mathrm{SiO}_{2}$} & 2.1 & - & - & 40 & Gelcasting \\
\hline & 1.95 & 3.18 & 0.00053 & 65.2 & Gelcasting and vibration \\
\hline$+2 \% \mathrm{Si}_{3} \mathrm{~N}_{4}$ & 1.96 & - & - & 37.13 & Gelcasting \\
\hline- & 1.95 & - & - & 59.2 & CIPing \\
\hline - & 1.97 & 3.32 & 0.0012 & 54.12 & CIPing \\
\hline - & $1.90-1.98$ & - & - & $50-65$ & CIPing \\
\hline \multirow[t]{2}{*}{-} & 1.94 & - & - & 64 & Slip casting \\
\hline & 2.09 & $\begin{array}{c}3.8 \\
\text { (X-band) }\end{array}$ & $\begin{array}{c}0.002 \\
\text { (X-band) }\end{array}$ & 69 & Arc fusion process \\
\hline $\mathrm{SiO}_{2} \mathrm{f} / \mathrm{SiO}_{2}$ & 1.65 & - & - & 75 & Sol-powder infiltration \\
\hline $\mathrm{SiO}_{2} \mathrm{f} / \mathrm{SiO}_{2}$ & - & $\begin{array}{c}3.16-3.29 \\
\text { up to } 1100^{\circ} \mathrm{C}\end{array}$ & $1.7-6.2 \times 10^{-3}$ & - & - \\
\hline Sol to fiber fabrics & 1.55 & $2.88-3.1$ & $\begin{array}{c}0.006 \\
\text { (at } 250 \mathrm{MHz} \text { ) }\end{array}$ & 35 & - \\
\hline Plus filler and coating & - & 3.25 & 0.0013 & 60.6 & - \\
\hline Plus filler and coating & - & $3.11-3.20$ & $0.0012-0.0013$ & $61.5-66.9$ & - \\
\hline
\end{tabular}

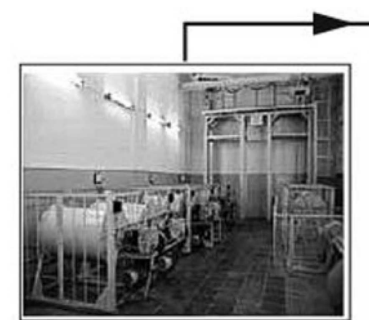

Production of highly concentrated slips

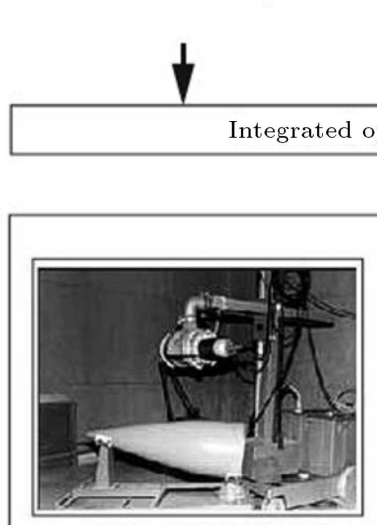

$\mathrm{X}$-ray quality control

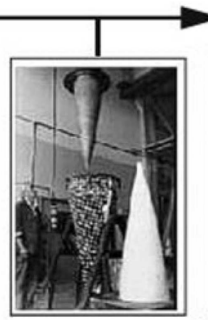

Formation of semifinished products

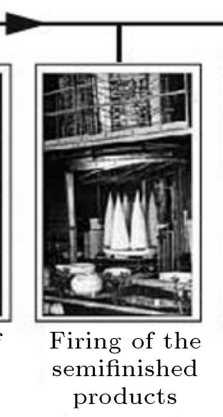

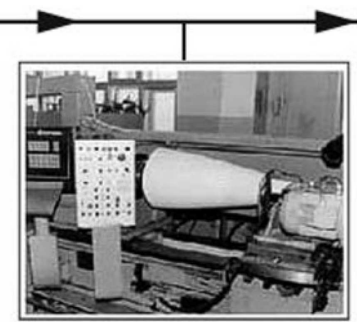

Machining of the semifinished
products

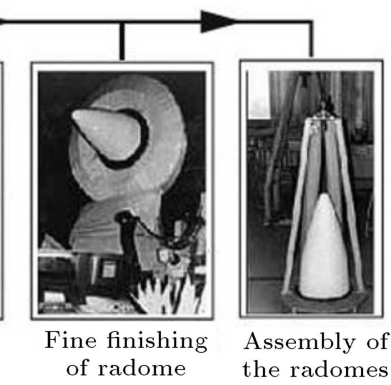

components the radomes
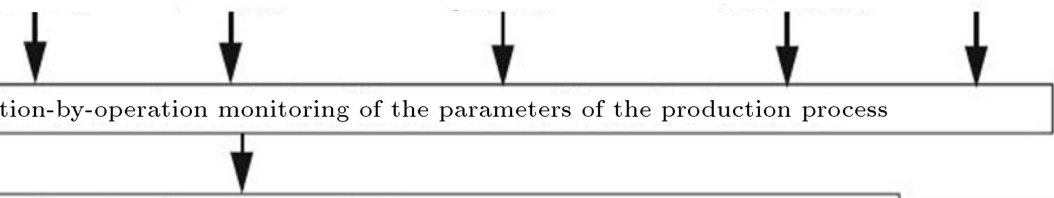

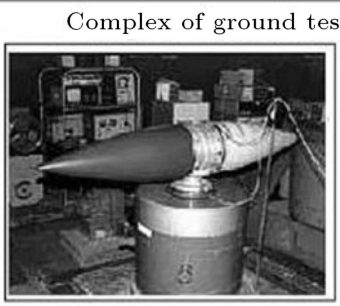

Testing for resistance to vibration and shock loads

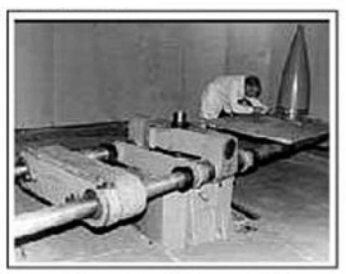

Linear-load testing

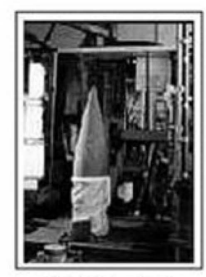

Testing for thermal conductivity

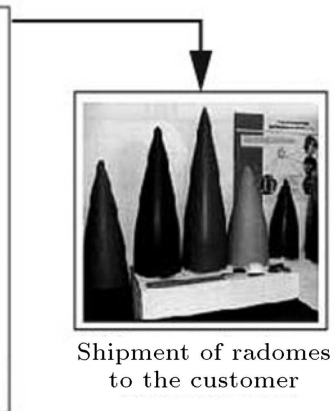

Figure 4. Flow diagram for the production of radomes made of quartz ceramics [20]. 
perature ranges and has a low loss tangent. The dielectric constant of this material remains constant up to $800^{\circ} \mathrm{C}$ and its loss tangent changes from 0.0002 at $100^{\circ} \mathrm{C}$ to 0.0014 at $800^{\circ} \mathrm{C}$. The thermal conductivity of quartz glass increases from $1.8 \mathrm{~W} /(\mathrm{m} . \mathrm{K})$ at the temperature range of $20-100^{\circ} \mathrm{C}$ to $2.7 \mathrm{~W} /(\mathrm{m} . \mathrm{K})$ at the temperature range of $20-800^{\circ} \mathrm{C}$ [2]. As a result of these properties, fused silica is also excellent structural and functional material in many different fields of application such as crucibles in metallurgy and polysilicon industry, thermal resistance materials in the aircraft industry, and high-temperature microwave-transparent materials. Fused silica ceramics are commonly made by fusion of pure silica sand with a silica content of approximately $99 \%[20,21]$.

The properties of ceramics based on fused silica are considerably lower than those of glass ceramics, and these properties are controlled by porosity. Thus, the use of quartz glass in missile radomes has been limited due to its high porosity and low mechanical strength. In exposure to ambient moisture, the electrical properties of porous ceramics diminish severely. The loss tangent of these ceramics increases substantially, even with the presence of minor humidity in the samples (higher than 0.3\%). Under real conditions, it is impossible to use quartz ceramics without a special cover. Applying an organic or inorganic cover to the surface of samples does not have much effect, and it is usually not desirable at temperatures above $250^{\circ} \mathrm{C}$. The low erosion resistance of porous materials towards the action of rain is noted, which leads to quick damage inflicted on their structure. Also, a high wear rate and formation of layering under high temperature conditions worsens the radio engineering characteristics of objects. The disadvantages of quartz ceramic limit its application for manufacturing rocket radomes for ship and aviation bases $[2,16]$.

\section{Silicon nitride}

The need for having high-temperature materials for radomes has attracted researchers' attention to silicon nitride $\left(\mathrm{Si}_{3} \mathrm{~N}_{4}\right)$ ceramics. This structurally important ceramic material has excellent mechanical and thermal properties for application in high-temperature radomes [16,22-24]. $\mathrm{Si}_{3} \mathrm{~N}_{4}$ ceramic is one of the most promising inorganic radome materials combining wave permeability, good high temperature strength, heat insulation and corrosion resistance, good thermal shock resistance, and a hotspot in the radome research field for its excellent comprehensive performance $[25,26]$. The properties of radomes based on $\mathrm{Si}_{3} \mathrm{~N}_{4}$, pyroceram, and fused silica are compared in Table 7 . In addition to radomes, porous silicon nitride ceramics are also used in industrial applications, such as catalytic carriers, filters for molten metals and in lightweight structural parts used in high temperature applications [27]. Addition of certain oxides to the sintering of silicon nitride is a well-known method for producing dense ceramics for engineering applications [28]. Many of the oxide materials, such as silicon carbide ( $\mathrm{SiC}$ ) [29,30], magnesium oxide $(\mathrm{MgO})$ [31], boron nitride $(\mathrm{BN})$ [32], yttria $\left(\mathrm{Y}_{2} \mathrm{O}_{3}\right)$ [33], zirconia $\left(\mathrm{ZrO}_{2}\right)$ [34], alumina $\left(\mathrm{Al}_{2} \mathrm{O}_{3}\right)$ [35], lutetium oxide $\left(\mathrm{Lu}_{2} \mathrm{O}_{3}\right)$ [36], and silica $\left(\mathrm{SiO}_{2}\right)$ [37,38], are used as sintering aids.

The applications of $\mathrm{Si}_{3} \mathrm{~N}_{4}$ depend on its molecular

Table 7. Comparing the properties of radomes based on $\mathrm{Si}_{3} \mathrm{~N}_{4}$, pyroceram, and fused silica [16].

\begin{tabular}{|c|c|c|c|c|c|c|c|c|c|c|c|c|}
\hline \multirow[t]{2}{*}{ Material } & \multicolumn{2}{|c|}{$\begin{array}{c}\text { Elastic } \\
\text { modulus } \\
\left(10^{6} \mathrm{psi}\right) \\
\end{array}$} & \multicolumn{2}{|c|}{$\begin{array}{l}\text { Expansion } \\
\text { coefficient } \\
\left(10^{-6} /{ }^{\circ} \mathrm{F}\right) \\
\end{array}$} & \multicolumn{2}{|c|}{$\begin{array}{c}\text { Thermal } \\
\text { conductivity } \\
\left(\text { Btu/ft h }{ }^{\circ} \mathbf{F}\right)\end{array}$} & \multicolumn{2}{|c|}{$\begin{array}{c}\text { Dielectric } \\
\text { constant }\end{array}$} & \multicolumn{2}{|c|}{$\begin{array}{c}\text { Loss } \\
\text { tangent }\end{array}$} & \multirow{2}{*}{$\begin{array}{c}\text { Maximum } \\
\text { use } \\
\text { temperature } \\
\left({ }^{\circ} \mathbf{R}\right) \\
\end{array}$} & \multirow{2}{*}{$\begin{array}{l}\text { Bending } \\
\text { strength } \\
\text { (psi) }\end{array}$} \\
\hline & $\mathrm{RT}$ & $\begin{array}{l}1500 \\
\left({ }^{\circ} \mathrm{F}\right)\end{array}$ & RT & $\begin{array}{l}1500 \\
\left({ }^{\circ} \mathrm{F}\right)\end{array}$ & RT & $\begin{array}{c}1500 \\
\left({ }^{\circ} \mathrm{F}\right) \\
\end{array}$ & RT & $\begin{array}{l}1500 \\
\left({ }^{\circ} \mathrm{F}\right)\end{array}$ & RT & $\begin{array}{l}1500 \\
\left({ }^{\circ} \mathrm{F}\right)\end{array}$ & & \\
\hline $\begin{array}{l}\text { HPSN } \\
\rho=3.2 \\
\left(\mathrm{~g} / \mathrm{cm}^{3}\right)\end{array}$ & 43.5 & 43.5 & 1.77 & 1.77 & 12.1 & 9.0 & 7.59 & 8.55 & 0.00275 & 0.0065 & 3870 & 58000 \\
\hline $\begin{array}{c}\text { RSSN } \\
\rho=2.4 \\
\left(\mathrm{~g} / \mathrm{cm}^{3}\right)\end{array}$ & 15.0 & 15.0 & 1.1 & 2.05 & 5.4 & 4.05 & 5.56 & 6.1 & 0.005 & 0.005 & 3870 & 20000 \\
\hline $\begin{array}{c}\text { SCFS } \\
\rho=1.926 \\
\left(\mathrm{~g} / \mathrm{cm}^{3}\right) \\
\end{array}$ & 8 & 10 & 0.45 & 0.175 & 0.31 & 0.40 & 3.4 & 3.5 & 0.0014 & 0.002 & 3600 & 4000 \\
\hline $\begin{array}{c}\text { Pyroceram } \\
9606 \\
\rho=2.6 \\
\left(\mathrm{~g} / \mathrm{cm}^{3}\right)\end{array}$ & 16.5 & 16.8 & 2.5 & 3.0 & 2.2 & 1.74 & 5.515 & 5.805 & 0.0003 & 0.01 & 2930 & 22500 \\
\hline
\end{tabular}


structure and properties such as space gap, permeation, thermal expansion, and hardness. These properties are themselves influenced by the type, length and angle of molecular bonds, and the crystalline structure and system. Only two polymorphs of $\alpha$ and $\beta$ are known to exist of this material [39]. Hardie \& Jack [40] have shown that both of these $\mathrm{Si}_{3} \mathrm{~N}_{4}$ forms are hexagonal. However, other researchers have reported that $\alpha$ phase has a rhombohedral structure, while $\beta$ phase has a hexagonal structure [41]. It is generally believed that $\alpha$ and $\beta$ are the low- and high-temperature forms of $\mathrm{Si}_{3} \mathrm{~N}_{4}$, respectively. Wild, Grieveson \& Jack [42] have suggested that $\alpha$ polymorph has a high oxygen potential, whereas $\beta$ polymorph has a low oxygen potential [43].

The unit cell of $\alpha-\mathrm{Si}_{3} \mathrm{~N}_{4}$ is twice the length of $\beta-\mathrm{Si}_{3} \mathrm{~N}_{4}$. The planes in $\alpha-\mathrm{Si}_{3} \mathrm{~N}_{4}$ have an 'ABCDABCD ...' configuration, while the planes have an 'ABAB ...' configuration in the $\beta-\mathrm{Si}_{3} \mathrm{~N}_{4}$. Thus, $\alpha$ $\mathrm{Si}_{3} \mathrm{~N}_{4}$ is harder than $\beta$-Si $\mathrm{N}_{3} \mathrm{~N}_{4}$, but $\beta$ phase is more stable at higher temperatures [22]. The mechanical properties of $\beta-\mathrm{Si}_{3} \mathrm{~N}_{4}$ are superior to those of $\alpha-\mathrm{Si}_{3} \mathrm{~N}_{4}$, while $\alpha-\mathrm{Si}_{3} \mathrm{~N}_{4}$ has better dielectric properties. During the sintering process, $\alpha-\mathrm{Si}_{3} \mathrm{~N}_{4}$ can be converted into $\beta-\mathrm{Si}_{3} \mathrm{~N}_{4}$ at a temperature range of $1750-1900^{\circ} \mathrm{C}$, and the phase transformation process is achieved through liquid phases [44]. Thus, the phase ratio $(\beta / \alpha)$ of the polycrystalline silicon nitride changes during the sintering process, and its mechanical properties are determined not only by the phase ratio $(\beta / \alpha)$, but also by the grain size and the combination of the secondary phase. The effects of the mechanical properties of $\mathrm{Si}_{3} \mathrm{~N}_{4}$ on $\beta / \alpha$ and on microstructure have also been reported. In structures that have elongated grains, the long-crack toughness and $\beta / \alpha$ ratio increase, while hardness diminishes [22]. The dielectric constants of $\alpha-\mathrm{Si}_{3} \mathrm{~N}_{4}$ and $\beta-\mathrm{Si}_{3} \mathrm{~N}_{4}$, at room temperature, are 5.6 and 7.9 , respectively, which are too high for the use of $\mathrm{Si}_{3} \mathrm{~N}_{4}$ as a radome. An effective method of reducing the dielectric constant in materials is to produce pores in them; however, pores can lower the mechanical properties of ceramic materials. Therefore, it is important to strike a balance between the mechanical properties and the dielectric constant. Moreover, it is difficult to fabricate large radomes with arbitrary shapes $[45,46]$.

Up to now, different methods have been employed for fabricating porous $\mathrm{Si}_{3} \mathrm{~N}_{4}$ ceramics, such as freeze casting method $[47,48]$, carbothermal reduction method [49], direct foaming method [50], sacrificial template method [51,52], etc. A common method is to add organic volatile materials or to use organic molds, producing pores after heating. Nevertheless, the elimination of the residual carbon impurity is usually difficult, and it highly affects the use of this material as a radome $[45,53]$. Another technique is the sintering of the compacted powder up to a specific temperature, which is called the partial sintering process. For example, porous $\mathrm{Si}_{3} \mathrm{~N}_{4}$ ceramics with $10-20 \%$ porosity and 200-300 MPa strength can be obtained through partial hot pressing. Other methods, including the reactive sintering of silicon powders by nitrogen, reactive sintering through the carbothermal reduction of $\mathrm{SiO}_{2}$ in nitrogen medium, freeze casting, and combustive sintering, have also been applied. Due to the covalent bonds, the compaction of $\mathrm{Si}_{3} \mathrm{~N}_{4}$ without adding a sintering aid would be difficult, and usually metal oxides, such as $\mathrm{Y}_{2} \mathrm{O}_{3}+\mathrm{Al}_{2} \mathrm{O}_{3}, \mathrm{Er}_{2} \mathrm{O}_{3}$, and $\mathrm{Yb}_{2} \mathrm{O}_{3}$, are used for the sintering of $\mathrm{Si}_{3} \mathrm{~N}_{4}$, accompanied by the formation of a liquid phase. However, this process still has a high sintering temperature. So, in order to obtain $\mathrm{Si}_{3} \mathrm{~N}_{4}$ ceramics at low temperature, lowtemperature liquid phases, such as $\mathrm{SiP}_{2} \mathrm{O}_{7}, \mathrm{MgO}-$ $\mathrm{Al}_{2} \mathrm{O}_{3}-\mathrm{SiO}_{2}$ system, $\mathrm{SiO}_{2}$, and boro-phospho-silicate $\left(\mathrm{SiO}_{2}-\mathrm{B}_{2} \mathrm{O}_{3}-\mathrm{P}_{2} \mathrm{O}_{5}\right)$, have also been used, yielding a porosity above $60 \%$ and a strength lower than $20 \mathrm{MPa}$ (Figure 5) [54]. Also, the dielectric constant of this material has been obtained in the range of 7.9-8.2 by the hot pressing method and in the range of 5.6-5.8 by the reactive sintering technique [55].

Using the slip casting technique for the $\mathrm{Si}_{3} \mathrm{~N}_{4}$ ceramics, a dielectric constant in the range of $3.7-4$ and a strength in the range of 63.9-143 $\mathrm{MPa}$ have been respectively obtained for the samples sintered at temperature range of $1300-1600^{\circ} \mathrm{C}$ and the frequency range of $12-18 \mathrm{GHz}$, which are suitable values for application in radomes.

Many researchers have suggested using the fibrous $\mathrm{Si}_{3} \mathrm{~N}_{4}$ matrix and saturating it with $\mathrm{SiO}_{2}$ and $\mathrm{BN}$. These substances $\left(\mathrm{SiO}_{2}\right.$ and $\mathrm{BN}$ ) have a lower dielectric constant relative to $\mathrm{Si}_{3} \mathrm{~N}_{4}$. Also, investigations have shown that the preforms obtained after the heat treat-

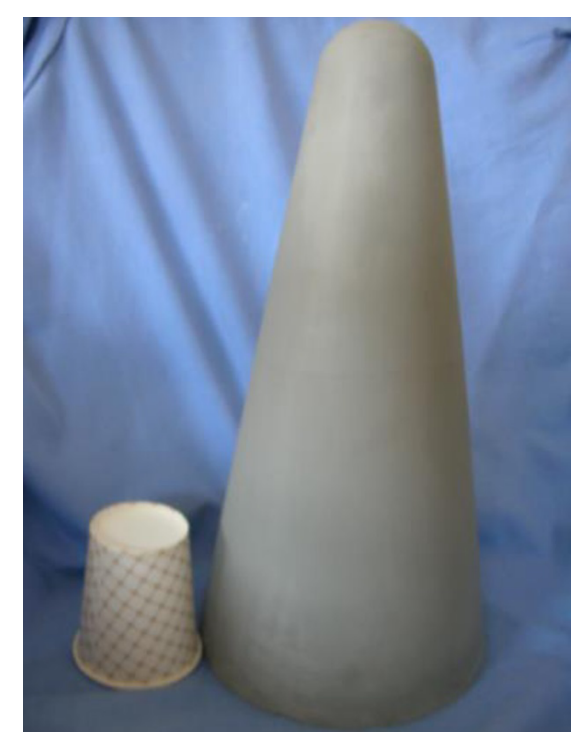

Figure 5. $\mathrm{Si}_{3} \mathrm{~N}_{4}$-based ceramic radome with $60 \%$ porosity made by the gas pressure sintering technique [54]. 
ment contain a large number of pores (12-20\%). With regard to dielectric properties, Nitroxyceram $\left(\mathrm{Si}_{3} \mathrm{~N}_{4^{-}}\right.$ $\left.\mathrm{BN}-\mathrm{SiO}_{2}\right)$ is as good as fused silica, and it is similar to pyroceram from the perspective of resistance against abrasion [2].

Another method of improving the mechanical properties of ceramics is to design sandwich type structures and to use different materials in combination. The residual thermal tensile stress in the interior layers and the residual thermal compressive stress in the exterior layers are produced as a result of the difference in the thermal expansion coefficient of different layers. The residual thermal compressive stress leads to crack deviation and the prevention of crack growth, thereby improving the mechanical properties. To improve the mechanical properties of porous $\mathrm{Si}_{3} \mathrm{~N}_{4}$ ceramics with a low dielectric constant, the sandwich structure should be designed so that the internal layer has a higher thermal expansion coefficient and a lower dielectric constant than $\mathrm{Si}_{3} \mathrm{~N}_{4}$. $\mathrm{BN}$ is a good material for this purpose. Due to the weak sintering ability of $\mathrm{BN}$, using a mixture of $\left(\mathrm{BN}+\mathrm{Si}_{3} \mathrm{~N}_{4}\right)$ is better than pure $\mathrm{BN}$. Many researchers have recently worked on the warm sintering of laminar ceramics $\mathrm{Si}_{3} \mathrm{~N}_{4} / \mathrm{Si}_{3} \mathrm{~N}_{4}+\mathrm{BN}$ and obtained porous ceramics with dielectric constants in the range of 2.93-5.89 [56].

Considering the above-mentioned information, it seems that by applying the pressureless sintering, slip casting, gel casting methods, and using different additives, high-strength materials with acceptable dielectric constants can be obtained, which are suitable for use as radomes. Also, large radomes with shapes close to the final design can be fabricated by using these techniques.

\section{Conclusion}

Advanced tactical missiles require radomes of higher strength capable of withstanding higher velocities and temperatures and longer flight durations. In meeting these requirements, it seems that silicon nitride $\left(\mathrm{Si}_{3} \mathrm{~N}_{4}\right)$ ceramics with properties, such as high strength, thermal stability, light weight, low thermal expansion, chemical stability, low dielectric constant, and high stiffness, are superior to other types of ceramics. Many research studies have been carried out recently to find the best technique for the fabrication of $\mathrm{Si}_{3} \mathrm{~N}_{4}$ radomes with a high mechanical strength and low dielectric constant and with shapes close to the ultimate shape.

The other materials that have been used for this purpose include the slip-cast fused silica and Pyroceram 9606 ( $2 \mathrm{MgO} .2 \mathrm{Al}_{2} \mathrm{O}_{3} .5 \mathrm{SiO}_{2}$, cordierite). Fused silica is produced by the slip-casting process, which is a simple technique, and the final product has a good thermal shock resistance as well as excellent dielectric properties for radome applications; however, the relatively low strength and low abrasion resistance of this material have limited its applications. Pyroceram 9606 is a magnesium-aluminum silicate compound with high thermal shock resistance and resistance against corrosion and abrasion. This material is more resistant against abrasion than fused silica; but dielectrically, it is not stable against temperature variations and cannot be used at speeds near Mach 5 .

\section{References}

1. Medding, J.A. "Nondestructive evaluation of zirconium phosphate bonded silicon nitride radomes", M.Sc. Thesis, Virginia Polytechnic Institute and State University, Blacksburg, Virginia (1996).

2. Suzdal'tsev, E., Kharitonov, D. and Anashkina, A. "Analysis of existing radioparent refractory materials, composites and technology for creating high-speed rocket radomes. Part 1. Analysis of the level of property indices and limiting possibilities of radioparent inorganic refractory materials", Refractories and Industrial Ceramics, 51(3), pp. 202-205 (2010).

3. Barta, J., Manela, M. and Fischer, R. " $\mathrm{Si}_{3} \mathrm{~N}_{4}$ and $\mathrm{Si}_{2} \mathrm{~N}_{2} \mathrm{O}$ for high performance radomes", Materials Science and Engineering, 71, pp. 265-272 (1985).

4. Cary, R., Avionic Radome Materials, DTIC Document, Royal Radar Establishment Malvern (United Kingdom), pp. 13-14 (1974).

5. Kandi, K.K., Thallapalli, N. and Chilakalapalli, S.P.R. "Development of silicon nitride-based ceramic radomes-A review", International Journal of Applied Ceramic Technology, 12(5), pp. 909-920 (2015).

6. Crowell Sr, G.A. "The descriptive geometry of nose cones", URL: http://www.myweb.cableone.net/ cjcrowell/NCEQN2.doc (1996).

7. Stoney, W.E.J. "Transonic drag measurements of eight body-nose shapes", NACA Research Memorandum L53K17, pp. 6-11 (1954).

8. Lin, S., Ye, F., Ma, J., Ding, J., Yang, C. and Dong, S. "Fabrication of multilayer electronic magnetic window material by $\mathrm{Si}_{2} \mathrm{~N}_{2} \mathrm{O}$ decomposition", Materials \& Design, 97, pp. 51-55 (2016).

9. Kandi, K.K., Thallapalli, N. and Chilakalapalli, S.P.R. "Development of silicon nitride based ceramic radomes - A review", International Journal of Applied Ceramic Technology, 12(5), pp. 909-920 (2015).

10. Chen, F., Shen, Q. and Zhang, L. "Electromagnetic optimal design and preparation of broadband ceramic radome material with graded porous structure", Progress in Electromagnetics Research, 105, pp. 445461 (2010).

11. Mortensen, A. and Suresh, S. "Functionally graded metals and metal-ceramic composites: Part 1 Processing", International Materials Reviews, 40(6), pp. 239265 (1995).

12. Hallse, R. and Rizley, J. "Fused silica as an aerospace material", Symposium on Newer Structural Materials for Aerospace Vehicles, ASTM International (1965). 
13. Cao, F., Fang, Z. and Zhang, C. "High-temperature properties and associated structure evolution of continuous SiNO fiber-reinforced BN composites for wave transparency", Materials \& Design, 43, pp. 258-263 (2013).

14. Liu, Y., Cheng, L., Zhang, L., Xu, Y. and Liu, Y. "Design, preparation, and structure of particle preforms for $\mathrm{Si}_{3} \mathrm{~N}_{4}(\mathrm{p}) / \mathrm{Si}_{3} \mathrm{~N}_{4}$ radome composites prepared using chemical vapor infiltration process", Journal of University of Science and Technology Beijing, Mineral, Metallurgy, Material, 15(1), pp. 62-66 (2008).

15. Xu, J., Zhu, D., Luo, F., Zhou, W. and Li, P. "Dielectric properties of porous reaction-boned $\mathrm{Si}_{3} \mathrm{~N}_{4}$ ceramics with controlled porosity and pore size", Journal of Materials Science and Technology, 24(2), pp. 207-210 (2008).

16. Crone, G., Rudge, A. and Taylor, G. "Design and performance of airborne radomes: A review", IEE Proceedings F (Communications, Radar and Signal Processing), IET, pp. 451-464 (1981).

17. Pavlov, V., Radome Materials, ONTI VIAM (AllUnion Institute for Aircraft Materials), pp. 101-105 (1966).

18. Miao, X.G., Qu, Y.R., Ghezzo, F., Fang, X.W., Yue, Y.T., Zhao, Z.Y. and Liu, R.P. "Fused silica ceramics and composites for radome applications", Advanced Materials Research, Trans. Tech. Publ., 900, pp. 123129 (2014).

19. Wan, W., Feng, Y., Yang, J., Bu, W. and Qiu, T. "Microstructure, mechanical and high-temperature dielectric properties of zirconia-reinforced fused silica ceramics", Ceramics International, 42(5), pp. 64366443 (2016).

20. Suzdal'tsev, E. "Radio-transparent ceramics: Yesterday, today, tomorrow", Refractories and Industrial Ceramics, 55(5), pp. 377-390 (2015).

21. Wan, W., Huang, C.-E., Yang, J., Zeng, J. and Qiu, T. "Effect of sintering temperature on the properties of fused silica ceramics prepared by gelcasting", Journal of Electronic Materials, 43(7), pp. 2566-2572 (2014).

22. Park, M.K., Kim, H.N., Lee, K.S., Baek, S.S., Kang, E.S., Kim, D.K. and Baek, Y.K. "Effect of microstructure on dielectric properties of $\mathrm{Si}_{3} \mathrm{~N}_{4}$ at microwave frequency", Key Engineering Materials, 287, pp. 247$252(2005)$

23. Zheng, G., Zhao, J., Li, L., Cheng, X. and Wang, M. "A fractal analysis of the crack extension paths in a $\mathrm{Si}_{3} \mathrm{~N}_{4}$ ceramic tool composite", International Journal of Refractory Metals and Hard Materials, 51, pp. 160168 (2015).

24. Fu, R. and Agathopoulos, S. "Nanostructure and bimodal structure of $\mathrm{Si}_{3} \mathrm{~N}_{4}$ ceramics developed by spark plasma sintering method", Advances in Applied Ceramics, 108(6), pp. 358-362 (2009).

25. Feng, Y., Gong, H., Zhang, Y., Wang, X., Che, S., Zhao, Y. and Guo, X. "Effect of BN content on the mechanical and dielectric properties of porous $\mathrm{BN}$ $\mathrm{p} / \mathrm{Si}_{3} \mathrm{~N}_{4}$ ceramics", Ceramics International, 42(1), pp. 661-665 (2016).

26. Lee, S.J. and Baek, S. "Effect of $\mathrm{SiO}_{2}$ content on the microstructure, mechanical and dielectric properties of $\mathrm{Si}_{3} \mathrm{~N}_{4}$ ceramics", Ceramics International, 42(8), pp. 9921-9925 (2016).

27. Yao, D., Xia, Y., Zeng, Y.-P., Zuo, K.H. and Jiang, D. "Porous $\mathrm{Si}_{3} \mathrm{~N}_{4}$ ceramics prepared via slip casting of $\mathrm{Si}$ and reaction bonded silicon nitride", Ceramics International, 37(8), pp. 3071-3076 (2011).

28. Tsuge, A., Kudo, H. and Komeya, K. "Reaction of $\mathrm{Si}_{3} \mathrm{~N}_{4}$ and $\mathrm{Y}_{2} \mathrm{O}_{3}$ in hot pressing", Journal of the American Ceramic Society, 57(6), pp. 269-270 (1974).

29. Bin, M., Zhaoyu, Y., Zhaohui, H., Minghao, F., Yangai, L. and Xiaowen, W. "Preparation and properties of sintering-free low density $\mathrm{Si}_{3} \mathrm{~N}_{4} / \mathrm{SiC}$ composite refractory", Rare Metal materials and Engineering, 44, pp. 490-493 (2015).

30. Jiang, Y., Wu, L.E. and Sun, W.Z. "Sintering behavior and properties of $\mathrm{SiC} / \mathrm{Si}_{3} \mathrm{~N}_{4}$ composite", Rare Metals, 34(2), pp. 95-100 (2015).

31. Terwilliger, G. "Properties of sintered $\mathrm{Si}_{3} \mathrm{~N}_{4}$ ", Journal of the American Ceramic Society, 57(1), pp. 48-49 (1974).

32. Li, B., Wang, S. and Cao, F. "Effect of sintering additives on properties of $\mathrm{Si}_{3} \mathrm{~N}_{4}-\mathrm{BN}$ composites fabricated via die pressing and precursor infiltration and pyrolysis route", Journal of Wuhan University of TechnologyMater. Sci. Ed., 29(5), pp. 891-894 (2014).

33. Tsuge, A., Nishida, K. and Komatsu, M. "Effect of crystallizing the grain-boundary glass phase on the high-temperature strength of hot-pressed $\mathrm{Si}_{3} \mathrm{~N}_{4}$ containing $\mathrm{Y}_{2} \mathrm{O}_{3}$ ", Journal of the American Ceramic Society, 58(7,8), pp. 323-326 (1975).

34. Ekström, T., Falk, L. and Knutson-Wedel, E. " $\mathrm{Si}_{3} \mathrm{~N}_{4}$ $\mathrm{ZrO}_{2}$ composites with small $\mathrm{Al}_{2} \mathrm{O}_{3}$ and $\mathrm{Y}_{2} \mathrm{O}_{3}$ additions prepared by HIP", Journal of Materials Science, 26(16), pp. 4331-4340 (1991).

35. Chen, J., Chen, K., Liu, Y.-G., Huang, Z.-H., Fang, M.-H. and Huang, J.-T. "Effect of $\mathrm{Al}_{2} \mathrm{O}_{3}$ addition on properties of non-sintered $\mathrm{SiC}_{-} \mathrm{Si}_{3} \mathrm{~N}_{4}$ composite refractory materials", International Journal of Refractory Metals and Hard Materials, 46, pp. 6-11 (2014).

36. Zheng, Y., Knowles, K., Vieira, J., Lopes, A. and Oliveira, F. "Microstructure, toughness and flexural strength of self-reinforced silicon nitride ceramics doped with yttrium oxide and ytterbium oxide", Journal of Microscopy, 201(2), pp. 238-249 (2001).

37. Li, M.L., Yu, Q., Xu, Y., Lu, Q.G. and Zhou, C.J. "Properties of $\mathrm{Si}_{3} \mathrm{~N}_{4}$ based nanocomposites prepared by pressureless sintering method", Advanced Materials Research, Trans. Tech. Publ., 532, pp. 53-56 (2012).

38. Wu, S. and Li, X. "Preparation of pure nano-grained $\mathrm{Si}_{2} \mathrm{~N}_{2} \mathrm{O}$ ceramic", International Journal of Refractory Metals and Hard Materials, 36, pp. 97-100 (2013). 
39. Li, J.L., Chen, F. and Niu, J.Y. "Low temperature sintering of $\mathrm{Si}_{3} \mathrm{~N}_{4}$ ceramics by spark plasma sintering technique", Advances in Applied Ceramics, 110(1), pp. 20-24 (2011).

40. Hardie, D. and Jack, K. "Crystal structures of silicon nitride", Nature, 180(4581), pp. 332-333 (1957).

41. Yamada, K. and Sawaoka, A. "Formation process of hopperlike $\beta-\mathrm{Si}_{3} \mathrm{~N}_{4}$ crystal formed by postshock vaporization and condensation of amorphous powder", Naturwissenschaften, 84(8), pp. 359-362 (1997).

42. Wild, S., Grieveson, P. and Jack, K. "The crystal structure of alpha and beta silicon and germanium nitrides", Special Ceramics, 5, pp. 385-395 (1972).

43. Axelson, S.R. "Preparation and evaluation of silicon nitride matrices for silicon nitride-SiC fiber composites", M.Sc. Thesis, Faculty of Alfred University, New York, pp. 3-18 (1988).

44. Duan, X., Jia, D., Deng, J., Yang, Z. and Zhou, Y. "Mechanical and dielectric properties of gelcasted $\mathrm{Si}_{3} \mathrm{~N}_{4}$ porous ceramic using $\mathrm{CaHPO}_{4}$ as an additive", Ceramics International, 38(5), pp. 4363-4367 (2012).

45. Zou, C., Zhang, C., Li, B., Wang, S. and Cao, F. "Microstructure and properties of porous silicon nitride ceramics prepared by gel-casting and gas pressure sintering", Materials \& Design, 44, pp. 114-118 (2013).

46. Xia, Y., Zeng, Y.-P. and Jiang, D. "Dielectric and mechanical properties of porous $\mathrm{Si}_{3} \mathrm{~N}_{4}$ ceramics prepared via low temperature sintering", Ceramics International, 35(4), pp. 1699-1703 (2009).

47. Hu, H.-L., Zeng, Y.-P., Xia, Y.-F., Yao, D.-X. and Zuo, K.-H. "High-strength porous $\mathrm{Si}_{3} \mathrm{~N}_{4}$ ceramics prepared by freeze casting and silicon powder nitridation process", Materials Letters, 133, pp. 285-288 (2014).

48. Xia, Y., Zeng, Y.-P. and Jiang, D. "Microstructure and mechanical properties of porous $\mathrm{Si}_{3} \mathrm{~N}_{4}$ ceramics prepared by freeze-casting", Materials \& Design, 33, pp. 98-103 (2012).

49. Cai, Y., Li, X. and Dong, J. "Microstructure and mechanical properties of porous $\mathrm{Si}_{3} \mathrm{~N}_{4}-\mathrm{SiO}_{2}$ ceramics fabricated by a process combining carbothermal reduction and sol-gel infiltration-sintering", Materials Science and Engineering: A, 601, pp. 111-115 (2014).

50. De Moraes, E. and Colombo, P. "Silicon nitride foams from emulsions", Materials Letters, 128, pp. 128-131 (2014).

51. Wu, J.-M., Zhang, X.-Y. and Yang, J.-L. "Novel porous $\mathrm{Si}_{3} \mathrm{~N}_{4}$ ceramics prepared by aqueous gelcasting using $\mathrm{Si}_{3} \mathrm{~N}_{4}$ poly-hollow microspheres as pore-forming agent", Journal of the European Ceramic Society, 34(5), pp. 1089-1096 (2014).

52. Zhang, X.-Y., Wu, J.-M. and Yang, J.-L. "Pore morphology designs of porous $\mathrm{Si}_{3} \mathrm{~N}_{4}$-based ceramics using $\mathrm{Si}_{3} \mathrm{~N}_{4}$ and $\mathrm{Al}_{2} \mathrm{O}_{3}$ poly-hollow microspheres as pore-forming agents", Materials Letters, 144, pp. 39$42(2015)$.
53. Zhao, M. and Zhang, Y. "Preparation of phosphate bonded silicon nitride porous ceramics in air", Procedia Engineering, 27, pp. 1313-1319 (2012).

54. Li, Y., Chen, F., Li, L., Zhang, W., Yu, H., Shan, Y., Shen, Q. and Jiang, H. "Gas pressure sintering of arbitrary porous silicon nitride ceramics with high mechanical strength", Journal of the American Ceramic Society, 93(6), pp. 1565-1568 (2010).

55. Zhang, R., Fang, D., Pei, Y. and Zhou, L. "Microstructure, mechanical and dielectric properties of highly porous silicon nitride ceramics produced by a new water-based freeze casting", Ceramics International, 38(5), pp. 4373-4377 (2012).

56. Zuo, K.-H., Zeng, Y.-P. and Jiang, D. "The mechanical and dielectric properties of $\mathrm{Si}_{3} \mathrm{~N}_{4}$-based sandwich ceramics", Materials \& Design, 35, pp. 770-773 (2012).

57. Stoney, W.E.J. "Transonic drag measurements of eight body-nose shapes", Research Memorandum, National Advisory Committee for Aeronatics, Washington (1954).

\section{Biographies}

Mina Saeedi Heydari received her BSc degree in Materials Science and Engineering from Iran University of Science and Technology, Tehran, Iran, and her MSc degree in Composite Materials from Faculty of Materials \& Manufacturing Processes, Malek Ashtar University of Technology, Tehran, Iran, where she is currently a PhD degree student in Material Engineering at Faculty of Materials \& Manufacturing Processes. Her research interests include ceramics, glass-ceramics, nano-materials, advanced ceramic materials, and composite materials.

Jalaleddin Ghezavati obtained his MSc degree in Mechanical Engineering of Agricultural Machinery from Bonab Branch, Islamic Azad University, Iran, BSc degree in Agricultural Machinery Engineering from Takestan Branch, Islamic Azad University, Iran, in 2008 and 2013, respectively. He is currently a PhD degree student in Mechanical Engineering at Bonab Branch, Islamic Azad University, Iran. From 2013 to present, he has been a member of Young Researchers and Elite Club, Bonab Branch, Islamic Azad University, Bonab, Iran. His field of research is Design and construction of Machine, Mechatronics, Post-harvest, nano Materials and Composite Materials.

Mahdi Abbasgholipour obtained his $\mathrm{PhD}$ and MSc degrees in Mechanical Engineering of Agricultural Machinery from the Tehran University, and BSc degree in Agricultural Machinery Engineering from the Tabriz University, Iran, in 2003, 2005, and 2010, respectively. From 2012 to the present time, he has been a department member of the Mechanical Engineering of 
Agricultural Machinery, the Islamic Azad University, Bonab Branch, Bonab, Iran. His field of research is machine vision and post-harvest.

Behzad Mohammadi Alasti obtained his BSc and MSc degrees in Mechanical Engineering of Agricultural Machinery from the Urmia University, Iran, and PhD degree in the same field from the Islamic Azad University, Science and Research Branch, Tehran, Iran, in 2004, 2006, and 2011, respectively. From 2011 to the present time, he has been a faculty member of the Mechanical Engineering Department, the Islamic Azad University, Bonab Branch, Bonab, Iran. His field of research is MEMS and NEMS. 